\title{
Ultrastructure of the forebody and foregut tegument and eccrine gland cells of Crepidostomum metoecus (Trematoda: Digenea: Allocreadiidae)
}

\author{
Zdeňka Žd'árská and Jana Nebesářová \\ Institute of Parasitology, Academy of Sciences of the Czech Republic, Branišovská 31, 37005 České Budějovice, Czech \\ Republic
}

Key words: Trematoda, Digenea, Crepidostomum metoecus, forebody and foregut tegument, eccrine gland cells, TEM

\begin{abstract}
The forebody and foregut of Crepidostomum metoecus Braun, 1900 are invested with a tegument bearing regularly arranged surface tubercles comparable with the aspidogastrean surface structures. The tegument of the ventrolateral lobes and of the prepharynx is penetrated by ducts of eccrine gland cells. The frontal and prepharyngeal gland cells, localised in the parenchyma, discharge electron-dense granules. Their ducts are lined by peripheral microtubules and fixed to the tegument plasmalemma by a septate junction. The functional roles of these glands are discussed.
\end{abstract}

The ultrastructure of the tegument of adult Crepidostomum metoecus Braun, 1900 has been studied using scanning electron microscopy (SEM) by Caira (1989) and Moravec (2002). This species has not yet been examined by transmission electron microscopy (TEM). Of the genus Crepidostomum Braun, 1900 two other species, C. opeongoensis Caira, 1985 and C. farionis (O.F. Müller, 1784), were studied in detail by SEM only (Choudhury and Nelson 2000, Moravec 2002).

In TEM, the ultrastructure of the forebody and of the foregut tegument of $C$. metoecus differs from that in other digeneans examined (Bogitsh 1972, Smyth and Halton 1983, Dunn at al. 1987, Žd'árská et al. 1990, Fried and Haseeb 1991, Fujino 1997, Halton 1997, Orido et al. 1998). The surface tegument displays small regularly arranged tubercles comparable with the surface tubercles in the Aspidogastrea (Rohde 1972, Fried and Haseeb 1991).

In the genus Crepidostomum, the eccrine gland cells present in the oral ventrolateral lobes and around the prepharynx of $C$. metoecus have not yet been studied. The existence of some gland cell ducts and openings only in the oral sucker lobes of Crepidostomum cooperi was reported by Caira (1989), and C. opeongoensis by Choudhury and Nelson (2000). The ultrastructure of these gland cells corresponds with the forebody gland cells described for other digeneans (Halton and Dermott 1967, Davies 1979, Žd'árská and Soboleva 1984, Fujino 1997). Also the ultrastructure of prepharyngeal gland cells, known in a few digeneans (Žd'árská et al. 1988, Orido et al. 1998), has not been studied in members of the genus Crepidostomum. In monogeneans, in contrast to digeneans, many types of eccrine gland cells penetrating the forebody and foregut tegument are known (Smyth and Halton 1983, Fried and Haseeb 1991).

\section{MATERIALS AND METHODS}

Specimens of Crepidostomum metoecus Braun, 1900 were removed from the intestine of Salmo trutta fario L., collected in the Czech Republic. They were washed in saline, fixed in $3 \%$ glutaraldehyde in $0.1 \mathrm{M}$ cacodylate buffer ( $\mathrm{pH} 7.2$ ) for $2 \mathrm{~h}$ at $4^{\circ} \mathrm{C}$, postfixed for $2 \mathrm{~h}$ at $4^{\circ} \mathrm{C}$ in $1 \%$ osmium tetroxide, dehydrated through an ethanol series and embedded in Durcupan via acetone. Series of ultrathin sections were cut using a Leica UCT ultramicrotome, double-stained with uranyl acetate and lead citrate and viewed in a JEOL 1010 transmission electron microscope operated at $80 \mathrm{kV}$. Semithin sections were stained with toluidine blue.

\section{RESULTS}

\section{Tegument}

The lining of the oral sucker, lobes, mouth, prepharynx, pharynx and oesophagus is composed of tegument which is continuous with and structurally similar to that of the general body surface. The surface of the forebody and foregut tegument is elevated into a series of regularly arranged tubercles (Figs. 1, 2, 4, 5, 9). The tegument distal cytoplasm contains mitochondria, ribosomes and electron-dense secretory bodies (Fig. 2). Other components occur regionally in the distal cytoplasm. The forebody is lined with a tegument with sensory endings, and the tegument of the ventrolateral lobe region is perforated by gland cell ducts (Figs. 1, 2).

The tegument of the foregut is without sensory receptors and its distal cytoplasm is regionally modified. In the mouth tegument there are concentrated large membraneous multilamellar bodies (Fig. 4). In the pharynx (Fig. 9), and mainly in the oesophagus, the distal cytoplasm forms long extensions. The basal plasmalemma of the tegument is closely connected with 


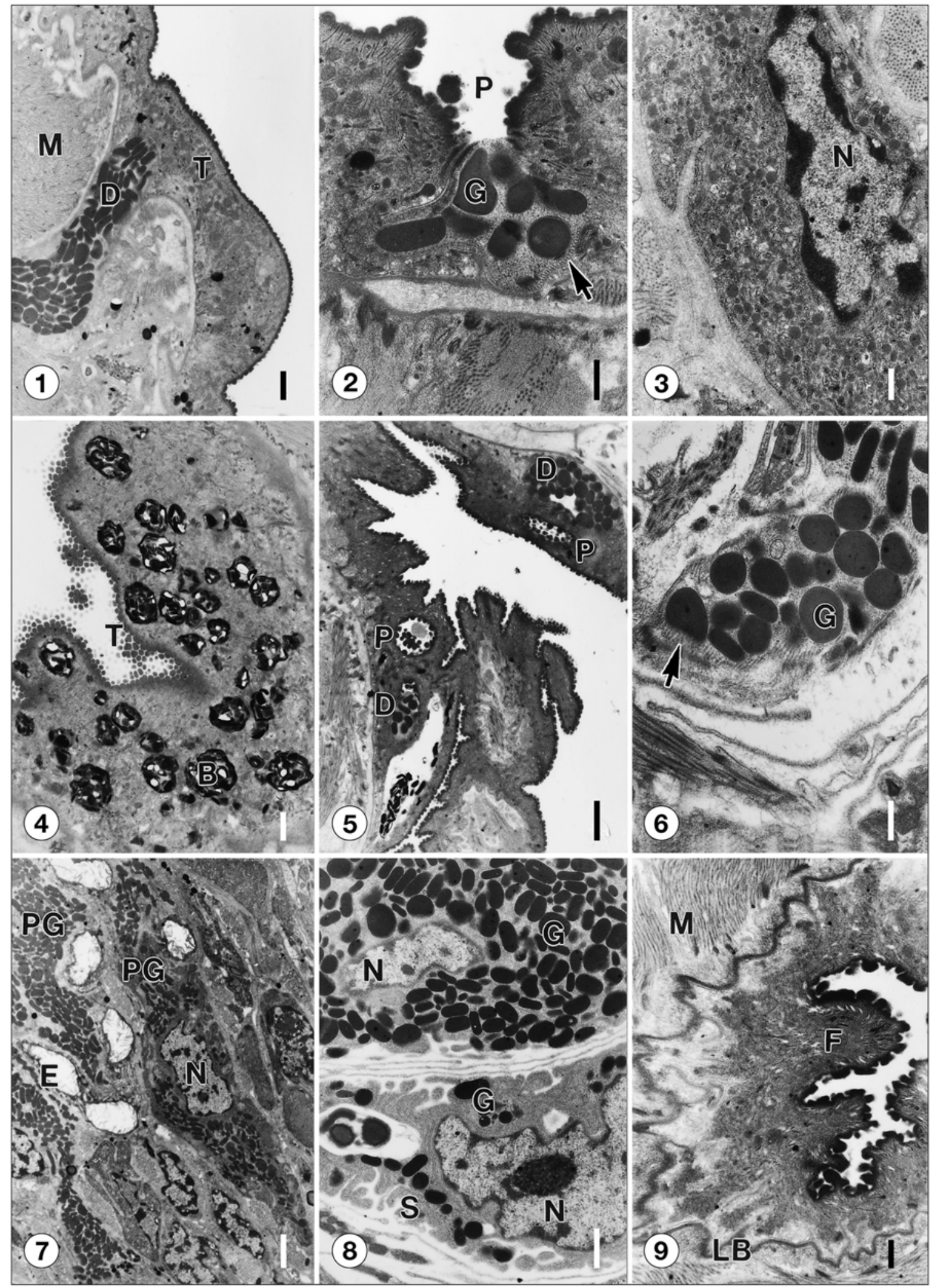


the basal lamina. At the sites where the distal cytoplasm connects with the processes of the tegumental cell bodies (Fig. 3), the basal lamina and fibrous layer is perforated. The ducts of the prepharyngeal gland cells also perforate the basal lamina and fibrous layer.

Eccrine gland cells of ventrolateral lobes (frontal glands)

These unicellular glands open to the exterior at the edge line along the anterior part of the ventrolateral lobes (Figs. 1, 2). The perinuclear parts of the gland cells are situated in the parenchyma below the thick muscle layer. The glands contain a large nucleus, granular endoplasmic reticulum with cisternae, Golgi complexes, mitochondria and large oval electron-dense secretory granules $(900 \times 500 \mathrm{~nm})$. The secretory product is concentrated in the considerably broadened ducts (Figs. 1, 2). The ducts are supported by longitudinal microtubules and attached to the basal tegument plasmalemma by a ring-like septate junction (Fig. 2). An electron-dense collar is juxtapositional to the junction.

\section{Prepharyngeal gland cells}

The prepharyngeal gland cells release their contents into the lumen of the prepharynx (Fig. 5). The perinuclear part of these glands is localised deep in the parenchyma between the oral sucker and pharynx (Fig. 7). The cytoplasm contains a large nucleus with nucleolus, granular endoplasmic reticulum with cisternae, Golgi complexes, mitochondria and large elliptical electrondense secretory granules $(750 \times 400 \mathrm{~nm})($ Fig. 8$)$. The surface of the cell bodies is irregular, forming small lobes (Fig. 8). Long narrow ducts transport the secretory granules to the prepharyngeal tegument. The ducts open at the base of the prepharyngeal tegument and release their contents into the lumen of the prepharynx (Fig. 5). The ducts are at the periphery reinforced by longitudinally arranged microtubules (Fig. 6). The apical part of the ducts penetrates the muscle and fibrous layers and basal lamina and is fixed to the tegument basal plasmalemma by a septate junction.

\section{DISCUSSION}

The ultrastructure of the tegument of Crepidostomum metoecus differs from that in other digeneans. The forebody and foregut (mouth, prepharynx, pharynx and oesophagus) are lined with a tegument bearing regularly arranged surface tubercles comparable with the aspidogastrean surface structures (Rohde 1972, Fried and Haseeb 1991). The pits at the gland cell openings are also surrounded by these tubercles. As in other digeneans, the forebody tegument bears sensory receptors. In the foregut tegument of $C$. metoecus, as in the foregut of Paragonimus miyazakii (Orido et al. 1998), no receptors were observed. Sensory receptors in the foregut of a digenean trematode have been detected in Megalodiscus temperatus only (Bogitsh 1972).

In adult digenean trematodes, in comparison with monogeneans (Smyth and Halton 1983), there is little information on the ultrastructure of forebody (Halton and Dermott 1967, Davies 1979, Žd'árská and Soboleva 1984, Fujino 1997), foregut (Davies 1979, Žd'árská et al. 1988, Orido et al. 1998), and their associated glands. The glands are designated according to the localisation at which the ducts of gland cells penetrate the tegument. In digeneans the forebody gland cells that open around the oral sucker are termed frontal gland cells (Halton and Dermott 1967, Davies 1979). In C. metoecus such glands could be designated the glands of the ventrolateral lobes.

In digeneans there are two types of glands opening into the foregut lumen, the prepharyngeal (Žd'árská et al. 1988, Orido et al. 1998) and oesophageal (Davies 1979) gland cells. In our opinion, in C. metoecus both types, the frontal and prepharyngeal gland cells, are involved in digestion. The frontal glands function in extracorporal digestion (and adhesion) as described in other digeneans (Halton and Dermott 1967, Davies 1979, Žd'árská and Soboleva 1984, Fujino 1997). In $C$. metoecus the secretory product of the frontal and foregut glands consists of electron-dense homogenous granules as in most other digeneans (Halton and Dermott 1967, Davies 1979, Žd'árská and Soboleva 1984, Žd'árská et al. 1988) except Paragonimus miyazakii (Orido et al. 1998).

Acknowledgements. We wish to thank Dr. F. Moravec for collecting the parasites. We also appreciate the technical assistance of Ing. B. Škoríková, Mr. A. Polák, Mgr. M. Vancová and Mrs. L. Nováková. This study was supported by a grant from the Grant Agency of the Czech Republic, No. $524 / 00 / 0267$.

Figs. 1-9. Crepidostomum metoecus, transmission electron micrographs. Fig. 1. Tegument (T) with regularly arranged surface tubercles of the oral sucker ventrolateral lobe, and duct (D) of frontal gland cell penetrating between the muscle fibres (M). Fig. 2. Detail of the frontal gland cell duct opening at the basal part of the tegument. Note the surface part of the pit tegument $(\mathrm{P})$ with tubercles. G - secretory granules; arrow - microtubules of the duct. Fig. 3. Perinuclear part of a tegumental cell with electron-dense secretory granules. N - nucleus. Fig. 4. Tangential section of the mouth tegument containing electron-dense membranous bodies (B). T - surface tubercles. Fig. 5. Prepharyngeal tegument penetrated by ducts (D) of prepharyngeal gland cells. $\mathrm{P}-$ pit at the duct opening. Fig. 6. Detail of the prepharyngeal gland cell duct. Arrow - peripheral microtubules; G secretory granules. Fig. 7. Perinuclear parts of prepharyngeal gland cells (PG) containing electron-dense secretory granules. $\mathrm{N}-$ nucleus; E - excretory duct. Fig. 8. Detail of perinuclear parts of two prepharyngeal gland cells. S - fine lobes of the gland cell surface; N - nucleus; G - secretory granules. Fig. 9. Transverse section of the pharynx. F - folds of tegument; LB - basal lamina; $\mathrm{M}$ - muscle fibres. Scale bars: Figs. 1, 4, $8=1 \mu \mathrm{m}$; Figs. 5, $7=2 \mu \mathrm{m}$; Figs. 2, 3, 6, $9=500 \mathrm{~nm}$. 


\section{REFERENCES}

BOGITSH B.J. 1972: Cytochemical and biochemical observations on the digestive tracts of digenetic trematodes. IX. Megalodiscus temperatus. Exp. Parasitol. 32: 244-260.

CAIRA J.N. 1989: A revision of the North American papillose Allocreadiidae with independent cladistic analyses of larval and adult forms. Bull. Univ. Nebr. State Mus. 11: 158.

CHOUDHURY A., NELSON P.A. 2000: Redescription of Crepidostomum opeongoensis Caira, 1985 (Trematoda: Allocreadiidae) from fish hosts Hiodon alosoides and Hiodon tergisus (Osteichthyes: Hiodontidae). J. Parasitol. 86: 1305-1312.

DAVIES C. 1979: The forebody glands and surface features of the metacercariae and adults of Microphallus similis. Int. J. Parasitol. 9: 553-564.

DUNN T.S., HANNA R.E.B., NIZAMI W.A. 1987: Ultrastructural and histochemical observations on the foregut and gut caeca of Gigantocotyle explanatum, Gastrothylax crumenifer and Srivastavaia indica (Trematoda: Paramphistomidae). Int. J. Parasitol. 17: 1141-1152.

FRIED B., HASEEB M.A. 1991: Platyhelminthes: Aspidogastrea, Monogenea and Digenea. In: F.W. Harrison and B.J. Bogitsh (Eds.), Microscopic Anatomy of Invertebrates. Vol. 3. Platyhelminthes and Nemertinea. WileyLiss, New York, pp. 141-209.

FUJINO T. 1997: Structure and function of the alimentary tract in trematodes. In: B. Fried and T.K. Graczyk (Eds.), Advances in Trematode Biology. CRC Press, Boca Raton, New York, pp. 87-115.
HALTON D.W. 1997: Nutritional adaptations to parasitism within the Platyhelminthes. Int. J. Parasitol. 27: 693-704.

HALTON D.W., DERMOTT E. 1967: Electron microscopy of certain gland cells in two digenetic trematodes. J. Parasitol. 53: 1186-1191.

MORAVEC F. 2002: External morphological differences between Crepidostomum farionis and Crepidostomum metoecus (Trematoda: Allocreadiidae), parasites of salmonids, as revealed by SEM. Folia Parasitol. 49: 211217.

ORIDO Y., KOKAZE A., AKAMATSU T., TAKASHIMA Y., YOSHIDA M. 1998: Ultrastructure of the foregut and associated glands in the lung fluke, Paragonimus miyazakii (Digenea: Troglotrematidae), with particular reference to their functional roles. J. Morphol. 237: 43-52.

ROHDE K. 1972: The Aspidogastrea, especially Multicotyle purvisi Dawes, 1941. Adv. Parasitol. 10: 77-151.

SMYTH J.D., HALTON D.W. 1983: The Physiology of Trematodes. Cambridge University Press, Cambridge, 446 pp.

ŽĎÁRSKÁ Z., SOBOLEVA T.N. 1984: Ultrastructure of the metacercaria and sporocyst sacs of Leucochloridium perturbatum Pojmanska, 1969. Folia Parasitol. 31: 133-139.

ŽĎÁRSKÁ Z., SOBOLEVA T.N., VALKOUNOVÁ J., ŠTĚRBA J. 1990: Ultrastructure of the general body tegument of the trematode Brachylaimus aequans. Helminthologia 27: 3-9.

ŽĎÁRSKÁ Z., ŠTĚRBA J., SOBOLEVA T.N., VALKOUNOVÁ J. 1988: Ultrastructure of the digestive system of Brachylaimus aequans (Trematoda: Brachylaimoidea). Folia Parasitol. 35: 105-111.

Accepted 14 June 2002 